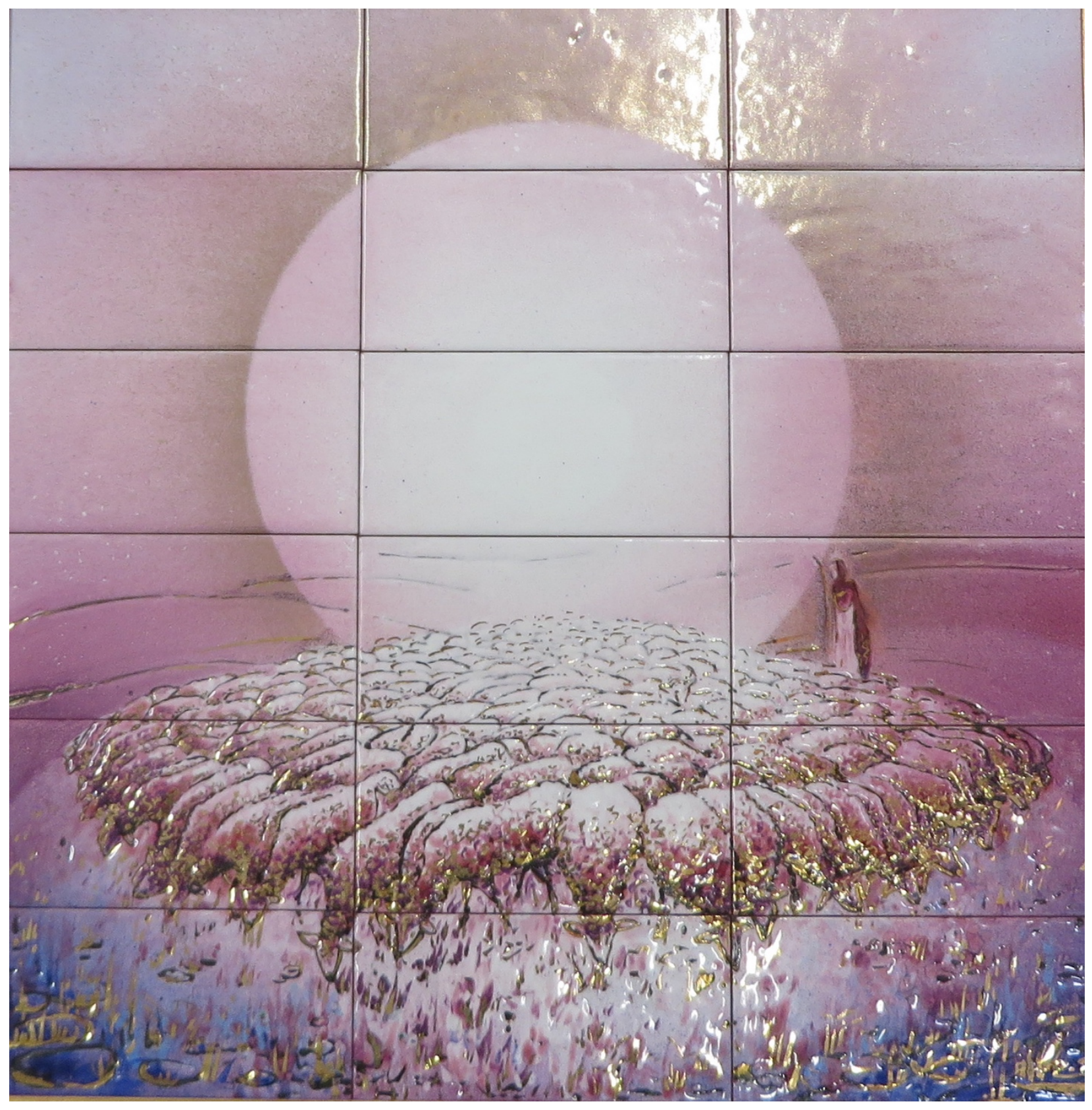

By María Cruz Bascones "Alpe," The Magnificat Number 18 


\title{
Colonial education in the Congo - a question of "uncritical" pedagogy until the bitter end?
}

\author{
La educación colonial en el Congo, ¿̇una cuestión de pedagogía "acrítica" hasta el \\ amargo final?
}

L'éducation coloniale au Congo - une question de pédagogie « non-critique» jusqu'à la fin?

\author{
Marc Depaepe \\ KULeuven@Kulak, Belgium
}

\begin{abstract}
Our approach is a historical, and not a theoretical or a philosophical one. But such an approach might help in understanding the complexities and ambiguities of the pedagogical mentalities in the course of the twentieth century. As is usually the case in historical research, the groundwork must precede the formulation of hypotheses, let alone theories, about the nature of pedagogical practices. Therefore, since the 1990s, "we" (as a team) have been busy studying the history of education in the former Belgian Congo. Of course, since then we have not only closely monitored the theoretical and methodological developments in the field of colonial historiography, but have ourselves also contributed to that history. This article tries to give an overview of some of our analyses, concentrating on the question of to what extent the Belgian offensive of colonial (i.e. mainly Catholic) missionary education, which was almost exclusively targeted at "paternalism," contributed to the development of a personal life, individual autonomy and/or emancipation of the native people. From the rear-view mirror of history we are, among other things, zooming in on the crucial 1950s, during which decade thoughts first turned to the education of a (very limited) "elite." The thesis we are using in this respect is that the nature of the "mental space" of colonialism was such that it did not engender a very great widening of consciousness among the local population.
\end{abstract}

Keywords: Belgian educational policy, Catholic missions, colonial education, Congo, educational historiography, history of education

\section{RESUMEN}

Aunque nuestro enfoque es histórico, no teórico o filosófico, podría ayudar a comprender las complejidades y ambigüedades de las mentalidades pedagógicas del siglo XX. Desde la década de 1990, nuestro equipo ha estudiado la historia de la educación en el Congo Belga centrándonos en el trabajo de base y las fuentes como trabajo necesariamente previo a la formulación de hipótesis y, mucho más, a la teorización sobre la naturaleza de las prácticas pedagógicas. Pero en este tiempo no sólo hemos seguido los desarrollos teóricos y metodológicos de la historiografía colonial, sino que también hemos contribuido a esa historia. Este artículo intenta dar una visión general de algunos de nuestros análisis, concentrándose en la cuestión de hasta qué punto la ofensiva belga de

Date of submission: 2017-09-08

Date of acceptance: 2017-11-03

ISSN 2560-8371

http://doi.dx.org/10.24908/eoe-ese-rse.v18i0.6859

(C) Encounters in Theory and History of Education 2 
la educación misionera colonial (es decir, principalmente católica), que era muy "paternalista", contribuyó al desarrollo de la educación para la vida personal, la autonomía individual y / o emancipación de los nativos. Desde el espejo retrovisor de la historia estamos, entre otras cosas, acercándonos a los cruciales años 50, durante los cuales el pensamiento educativo colonial se dirigió a la educación de una (muy limitada) "élite". La tesis que estamos manejando es que el "espacio mental" del colonialismo no era de una naturaleza tan grande como para permitir un gran aumento de conciencia entre la población local.

Palabras clave: Política educativa belga, misiones católicas, educación colonial, Congo, historiografía educativa, historia de la educación

\section{RÉSUMÉ}

Notre approche est historique et non théorique ou philosophique. Mais une telle approche pourrait aider à comprendre les complexités et les ambiguités des mentalités pédagogiques au cours du vingtième siècle. Comme c'est le cas en recherche historique, le travail préparatoire doit précéder la formulation d'hypothèses, et même les théories sur la nature des pratiques pédagogiques. Donc depuis les années 1990, comme équipe, nous avons été occupés à étudier l'histoire de l'éducation dans l'ancien Congo belge. Et puisque nous avons non seulement suivi de près les développements théoriques et méthodologiques dans le secteur de l'historiographie coloniale, nous avons aussi contribué à cette histoire. Cet article tente de donner une vue d'ensemble de certaines de nos analyses en nous concentrant sur la question suivante: À quel point l'offensive belge de l'éducation missionnaire coloniale (largement catholique), visant presqu'exclusivement au «paternalisme», at-elle contribué au développement de la vie et de l'autonomie personnelles et/ou à l'émancipation des indigènes? Du rétroviseur de l'histoire, nous faisons un zoom sur les années 1950 qui sont cruciales, car durant cette période, l'attention est portée premièrement sur l'éducation d'une (bien petite) «élite». Notre thèse à cet égard est celle-ci : «L'espace mental» du colonialisme n'était pas de nature à élargir la conscience parmi la population locale».

Mots-clés: La politique éducative belge, les missions catholiques, l'éducation coloniale, le Congo, l'historiographie éducative, l'histoire de l'éducation 
"Education may well be, as of right, the instrument whereby every individual in a society like our own, can gain access to any kind of discourse. But we well know that in its distribution, in what it permits and in what it prevents, it follows the well-trodden battle-lines of social conflict. Every educational system is a political means of maintaining and modifying the appropriation of discourse, with the knowledge and the powers it carries with it."

(Foucault, 1971, p. 227)

\section{A question's genesis as a starting point}

In his famous essay on the Enlightenment, Kant proclaimed the dawn of a new era, of a new individual, in a new society. As a consequence of sloth and the ease with which people had submitted themselves to the rule of the ecclesiastical and worldly (feudal) authorities until then, humankind had, according to Kant, refused to stand up for itself. It was for that reason that Kant called upon the individual to become more independent, to rely upon their own intellect and not upon what others impressed upon them. He considered education to be an individual responsibility, not the purview of institutions outside him. As such, education, and this was a relatively new idea at the time, was perceived as self-education. In causing oneself to be guided by reason, the instinctive nature could be mastered, thus paving the way for the development of natural aptitudes. Despite the fact that education was self-education, the individual was still forced to reply upon temporary assistance. According to Kant, this assistance had to be organised efficiently. As a result, the experiences acquired by previous generations of educators - so to speak about the art of "education" - had to be transformed into scientific knowledge. In so doing, Kant, from the outset, considered educational science to be a practical philosophy, buttressed by the field of tension bridging the empirical (i.e. at that time the historical) on one side and philosophical reflection on the other. Philosophical ethics would provide insights into the perfection of human development, whereas scientific study of experience would reveal the development potential of natural aptitude. In short, Kant saw education as a means of advancing humankind toward its own perfection, i.e., autonomy, or rather the emancipation of the individual (Depaepe, 2002).

The question that has occupied me as a historian of education since ages past is that which seeks to discover what has become of this ambitious Enlightenment Plan (see, e.g. Depaepe, 2012). Rather than having led to a process of emancipation, this late eighteenth-century pedagogical optimism mainly seems to have embodied itself in the "educationalization" of children's lives. Apparently, the myth of the perfectibility of the individual and the world was appropriated to force the individual (still at a nascent stage of education/emancipation) to conform to the desiderata of a modern, i.e., civil society. At the very least, modernization's process of social transformation led to the emergence of the bourgeoisie as the new, dominant group. It is based on this reasoning that we have, since the mid-Nineties, dedicated so many works to this idea of "educationalization," pertaining to the development of the educational mentality and reality in the West - and primarily in "our" regions (the Netherlands, Belgium, Flanders) - as an important element of this modernisation process (Depaepe et al., 2008).

Being a child became, certainly with the take-off of the so-called schooling society, educationally ordered. Thanks to the authority and the morality of the teacher, the moulding of pupils in the direction of socially desirable behaviour was made possible. Foucault (1971), from whom we took the quotation that was used as a motto for the 4th International Conference on 
Critical Pedagogies and Philosophies of Education, ${ }^{1}$ has introduced the well-known schemes of normalization, disciplinarization, biopolitics and so on, to better comprehend these phenomena. However, such coarse-grained "grand theories," which have been abundantly used up to now in the history of education (see, e.g., Roland, 2017), may well orient the disciplinary strategy that is expressed through education as well as the resistance it may generate in the crowd to be disciplined, but, following Tenorth (1996) and others, we think that educational historiography needs much more theory-building from within, and not from theorems that were mainly developed outside the specific context of the educational past. Educationalization, although often used as a container concept, might be a step in this direction, along with the idea of an existing "grammar of schooling." The archaeology of teaching and educating, with their associated rituals of school life undeniably follow a quasi-universal pattern and exude, certainly in the West, almost the same pedagogical semantics.

In view of the imperialism which inspired the launch of the European colonisation of Africa in the late nineteenth century, one can assume that analogous processes must also have been at work in colonial contexts, albeit on a smaller, but probably even more intensive scale, and therefore having characteristics that are likely to be more pronounced. After consulting several source materials on the development of education in Belgium's sole colony (1908-1960) -which, despite being a colossal 77 times larger than Belgium, was often introduced as the "tenth province" - we became convinced that the structure and the consequences of "modern" pedagogical life, including the systemic errors, would become best visible in a colonial context, where people, often based on the rather naïve belief in the supremacy of western (read Catholic) culture, saw a complete overhaul by modernisation as a necessity. For internal use we labelled that process "high-pressure cooking." However, before any decent speculations could be arrived at (Depaepe, 1997), we of course needed to have enough evidence at our disposal. In terms of educational historiography, not a single reference work could be had relating to the former Belgian colony. So we had to create our own, based on thorough research of the sources, because even the existing partial studies proved de facto too limited to allow for arriving at a true compendium. As is usually the case in historical research, the groundwork, too, had to precede any formulation of theory.

As a result, the book published in 1995 as the fruits of our first Congo project mainly focussed on the actual developments in education, with a special emphasis on how this played out in the Catholic missions (Depaepe and Van Rompaey, 1995). In the sphere of pedagogy the missions were able to clearly establish dominance (with about three quarters of all the institutions) vis-à-vis their rivals, the Protestants, during the colonial period. We divided our research into three levels, largely in analogy of the existing educational classifications: the colonial educational policy in tandem with the policy of the Catholic missions (the "macrolevel"), the near constant increase in the educational offer (the "mesolevel"), and the impact of all this on the people concerned (the "microlevel").

In the aforementioned educationalization process, we were most intrigued by the latter aspect. However, it was precisely at this level where the lack of sources was most keenly felt. The information that had been preserved in missionary archives mostly related to the first two levels. When we were able to penetrate the third level, thanks to letters to superiors, these personal reflections and comments were very one-sided, i.e., they usually derived from Belgian educational providers or facilitators, at least for the Catholics. Despite potential differences of opinion about the organisation of certain aspects, these educational facilitators were not burdened by any doubts

${ }^{1}$ 27th and 28th July 2017, University of Winchester, United Kingdom. At this conference a preliminary version of this article was presented as a keynote. 
concerning the direction in which the colonial project had to evolve. Church, state and industry all served the transcendent civilising mission, to the greater good and glory of the Belgian nation (Depaepe, 2014).

There is little more that needs to be said about how this consensus concerning the "imperial" Congo project was also characteristic of Belgium's colonial historiography in the years that followed (and in extension thereof, of its didactic deployment in textbooks for the teaching of Belgian history). With the monarchy as the point around which all revolved, colonial history was obliged to reinforce Belgium's unity and identity. However, it clear that this white epic is now completely outdated (among others, as a result of the "revisionist" opinions in relation to King Leopold II's high-handed approach, which made their definitive breakthrough starting in the Eighties and Nineties). Recently, Congolese historiography has once again begun to attract attention in the run up to the fiftieth anniversary of Congolese independence, in 2010. This has culminated in further developments on the theoretical and methodological level, to the extent that it touches on the material covered here.

Increasingly there is a tendency to focus on the "inverse" effects of colonisation. This means that historians not only focus on the extent of Congo's impact on Belgium, but likewise on the extent to which effort was made to integrate the African perspective in historiography and education at the time. Obviously, the colonial adventure has two sides, which is why a platform is necessary for the voice of the Congolese to be heard too. This first occurred in the Congo itself, with authors such as Valentin Mudimbe (E.g. 2009), to name but one, who provided a more anthropological and ethnographic basis for history. However, Belgian (in this case Flemish) researchers also availed themselves of this opportunity. The best-known example of this approach is incontestably David Van Reybrouck's masterful book on the history of Congo (Van Reybrouck, 2010), which has since become an international success in various translations.

The shift in emphasis is linked to the interest in the study of other, relatively new source materials, such as self-narratives, (auto)biographies and above all oral testimonies from both Congolese and Belgians, with the latter, however, sometimes interspersed with hints of nostalgia. Alongside this preference for oral history, the new access to audio-visual materials - historical photos, (propaganda) films, radio reports and so on - also played an important role; I will use some of them within the context of this article. ${ }^{2}$

For that matter, with regard to achieving a more in-depth analysis of the pedagogical past of Congo, our team has not disappointed in its efforts. Following the ground-breaking work of Honoré Vinck (2007, e.g.), one of the driving forces behind Mbandaka's Centre Aequatoria, we studied Congolese textbooks (Depaepe et al., 2003) - often the only books that children would ever see and we also studied the songs sung at school (Kita and Depaepe, 2004). The latter was made possible by our Congolese colleague Pierre Kita, with whom we were able to partner in Belgium for a period. Although initially not our intention, the serious involvement of Congolese peers naturally guaranteed a more nuanced perspective on the categorical effects of the Belgian pedagogical regime on the indigenous population. This was also the case in a number of interviews in Kinshasa and Brussels (in the Matonge neighbourhood), where we asked several Congolese about their school experiences (Vinck et al., 2006). This took place with a focus on the potential role that education, contrary to all the carefully orchestrated paternalism, may have played within the context of the development of a personal life, individual autonomy and/or emancipation.

\footnotetext{
${ }^{2}$ Originally, this article was conceived as a "lecture for the XXIst Century" - a series of interdisciplinary lectures in Dutch at the KU Leuven (University of Leuven), which can be followed as part of their curriculum by all master students. The preliminary text of this lecture has been published as Depaepe, 2017.
} 
Needless to say, this is one of the history of education's most intrinsic questions because it relates to the essence and the fulfilment of every educational initiative. And yet a response within educational historiography has only been marginally forthcoming at best. As has already been suggested above, the somewhat patchy response relates to the specificity and the normative nature of the source materials accumulated on education (Depaepe and Simon, 2009). However, delving into these methodological issues would take us too far off track.

\section{The current situation as departure point for a hypothesis}

To put it mildly, the fact that education in the Democratic Republic of Congo (DRC) finds itself in murky waters can be sussed out in the reading of a variety of sources. Distressing references to this pop up all over the internet on a regular basis. One of the most recent is from Yoon Jeong Na (2016), official UNICEF reporter on education in the DRC. She tries to get to the heart of the matter in twenty points: school drop-outs are high (3 out of 10 children fail to complete primary education), especially among girls (only 6 out of 10 girls manage to graduate, compared to 8 out of 10 boys); children have fallen behind too much (44\% of the children in first grade are older than six years of age); there are not enough schools outside of major town or city centres; there is too little funding for education (only $15 \%$ of the government budget, meaning that three quarters of the education expenditure must be borne by the families themselves); teachers are paid too little or in some cases nothing at all (half of all teaching staff receive no pay, i.e., $42 \%$ of the teachers in primary education and $87 \%$ of the teachers in pre-school education); the number of properly qualified teachers is too low (in secondary education only $17 \%$ of the teachers have the required qualifications, compared to $97 \%$ in primary education); there are not enough female educators (only $27 \%$ in primary education and $11 \%$ in secondary education, which contrasts immensely with the high level of feminisation in richer countries such as Belgium), and so on.

All these matters were addressed systematically in a World Bank Report (Fredriksen, 2005). It qualified the DRC as one of the five least "educated" countries in the world. While data collection is certainly no simple feat in such a vast country with a population so incredibly diverse in terms of ethnicity, language and culture (estimates are put at 200 to 400 ethnic groups, which are associated with 250 to 700 local languages, see also Fraiture, 2008), and which is constantly subject to migration flows, and what's more, being embroiled in internal conflicts and foreign wars and with school attendance being far from the norm, we still hold to the understanding that this report offers the most reliable figures for the situation at the start of the twenty-first century. In any case, we do not have time, nor sufficient data to problematize here the "fabrication" of education statistics, which the government and other organising bodies so often apply as window-dressing. Such fabrication is, of course, not limited to present-day Congo, but was already an issue in the nineteenth century and by extension throughout the first half of the twentieth century in Belgium, where educational statistics have been used as a policy instrument too (Minten et al., 1991-1996). However, to what extent both situations can be compared remains, all in all, very questionable.

What is clear, however, is that to-date the general structure of education in Congo bears the tell-tale mark of the Belgian education system; they have the same three levels, namely primary education (six years), secondary education (six years for general secondary education, practical and technical education and five years for vocational education) and higher education (divided into university and higher pedagogical and/or technical education, ranging from four to five, or even seven years). In the 2001-2002 academic year, there were about 19,100 primary schools for 5.7 million pupils, taught by approximately 159,000 teachers. Secondary education consisted of about 8,200 schools with 1.6 million pupils and 110,000 teachers. Finally, there were 326 higher 
education institutions at the time with about 200,000 students. Today the number of higher education institutions has more than doubled. The number of so-called universities has since increased to more than six hundred, which naturally results in a preponderance of qualifications and degrees. Given the precarious financial situation and widespread corruption (with students forced to bribe, either in money or favours, in exchange for tutoring or to pass exams) such inflation should then come as no surprise (see, in this respect, also De Herdt \& Titeca, 2016).

Furthermore, the hybridity between several private educational systems and one public system (including the confusion between these two "pillars" due to the privatisation of the public sector on the one hand and the subsidising of private sector on the other), can be seen as a typical Belgian heritage (Poncelet et al, 2010). Besides this "pillarization" of the educational supply, Catholic dominance also serves as a reminder of the Belgian colonial past. At the dawn of the twenty-first century, $80 \%$ of the Congolese population could still be said to be "Christian," generally speaking, the majority being Catholic, although the Protestant community was anything but negligible. In addition to the Catholic schools, several Protestant denominations also operate their own schools. In addition to these, there is also Kimbanguist education. ${ }^{3}$ The Kimbanguist Church was the first independent African church. And simultaneously, there are also several Muslim schools. Depending on the organising authority, and whether or not it receives grants, primary (including pre-school) education and secondary education can be subdivided into three categories: "public non conventionné" (public schools); "public conventionné" (most Catholic schools, which may receive funding from their respective congregations) and "privé." The higher education system only has "public" and "private" schools. In primary education, the "traditional" (conventionné) public schools, with Catholics comprising the lion's share, account for more than $70 \%$, and over $75 \%$ when it comes to the total student population. In secondary education, the share for both indicators was about $5 \%$ lower respectively.

Since Congo's independence, the evolution in the number of enrolments in primary education reflects a near constant growth from about 1,250,000 boys and 500,00 girls in the 1960-1961 academic year to just over 3,000,000 boys and just under 2,000,000 girls for the 2001-2002 academic year, with the exception of a significant decline in this curve during crisis years: 19891990 and 1999-2000. In addition, the record figure of 1995-1996 (which exceeded 3,500,000) was never achieved again for boys. However, in absolute numbers this development does not necessarily mean that the relative "educational attendance" (expressed as the ratio between the number of pupils and children of the same age) also went up. On the contrary, whereas the estimated educational attendance among boys was still about $100 \%$ in the mid-Eighties, it dropped to about $70 \%$ at the beginning of the current century. For girls, this regression translated to a drop from about $66 \%$ to $56 \%$. In secondary education, this regression was significantly less noticeable; however, the rate of enrolment fluctuated around a mere $30 \%$ for boys and $15 \%$ for girls. It is only starting in the initial independence years that a spectacular increase in educational enrolment (from $3 \%$ to $30 \%$ for boys and from $1 \%$ to $17 \%$ for girls) can be observed. In primary schools, enrolment for the entire period has dropped from $70 \%$ to $64 \%$ (this can exclusively be attributed to the decline in enrolment among boys from $102 \%$ [sic] to $72 \%$, whereas the girls' enrolment reflects an overall growth from $39 \%$ to $56 \%$ ).

Naturally, quantitative indicators only paint a very partial picture of the quality of Congolese education at the beginning of this century. According to the authors of the World Bank report, it was inadequate on every level, and despite the challenging context, far-reaching political choices

\footnotetext{
${ }^{3}$ This goes back to Simon Kimbangu who "stood up" as a prophet in 1921, using the language of divination and witchcraft. See MacGaffey, 1982, p. 246ff.
} 
needed to be made, however difficult (to include generalization of primary education, in addition to serious financial efforts, see Fredriksen, 2005; also De Herdt and Titeca, 2016).

From the rear-view mirror of history, however, we can ask ourselves how it came to this. For ages, the Belgian policy-makers (both the civilian and the spiritual) were convinced that it was precisely through investing in primary education that they could improve the situation, and that, in doing so, they did a great job. What was it then that went so terribly wrong rendering the colonial dream of development through "gradual" integration into the system impossible? Had they underestimated the (side) effects of the pedagogical civilising process that they themselves had set in motion? Or were their efforts far too lopsidedly focused on the implementation of a "civilising offensive" through discipline, rooted not only in a foreign culture regarded as being superior, but which above all provided little margin for personal development, becoming an outlet instead for frustrations pent up for far too long, the fruits of alienation and exclusion? Did the start in developing a general secondary, higher and university education system not come far too late, meaning that when independence transpired, the African frameworks needed for taking control of society were missing, as Mobutu repeatedly bore witness to in the Eighties and Nineties? Or was this just an all too easy explanation, to soothe the conscience of the colonists, designed to reinforce their belief that the Congolese were far from ready for this responsibility?

I think that ultimately there was more to it (Depaepe and Hulstaert, 2015). New leaders such as Mobutu had internalised the mental, social and spatial structures of colonialism, introduced to them by the headstrong paternalism of the Belgians, to such a degree that they could do nought but give rise to grotesque, neo-colonial exaggerations. As a result, the call for Africanisation and related pursuits of authenticity were doomed to fail (see also Depaepe, 1998). This was because it was largely founded on a strange amalgam of biblical/Christian metaphors about the adoration of a Messiah on the one hand and a purportedly African sociology of primitive purity on the other, which ultimately based itself on overly romantic European stereotypes to exactly the same extent.

Without wanting to assert that what a child learns at school determines his or her entire personality - because this would be a real example of "educationalization" (in the sense of ascribing too much power to education) - I will try to demonstrate in the following that during the colonial period (1908-1960) the developmental opportunities of those who experienced colonial Congo's educational policy were, for the most part, minimal. Of course, this thesis is, generally speaking, not very new. Almost immediately after the Congolese independence the colonial educational system was said to be inadequate (Hanf, 1969) due to, among other things, its structural problems (Yates, 1963 \& 1971). Therefore, it came as no surprise that education would lead to social disintegration and to the bankruptcy of its own institutions (Celis 1990). Some of the foreign critics at the time called the system a "poor pudding" - the nation was unprepared for self-government; Congo seemed to be a sample of what happens when "undereducated" people are granted independence (see Roobrouck, 2005, p. 74). What might be new, however, is the reformulation of the thesis within the conceptual framework of the history of education itself, its patterns, effects and consequences (Depaepe \& Simon, 1995).

\section{Colonial educational initiatives in Congo: the problem of a "tutelage" without end}

For the purpose of a potential international comparison, we summarised the pedagogical policy options of the Belgian colonial authorities during the first half of the twentieth century in four points (Depaepe, 2013): (1) support for the Catholic network of mission schools, even in its conflicts with the Protestant network; (2) near exclusive focus on primary education, stressing moral education over the acquisition of knowledge; (3) a marked preference for using the native 
linguae francae, rather than the French spoken in the metropolitan areas (or even Dutch); (4) the fundamental pedagogical attitude of tutelage - which we happened to borrow from the title of our first monograph on education in Congo. Before World War II, emancipation was not any more of a priority for the motherland than it was for her colonies. The first change or differentiation in the pattern of these related strategies is only apparent from the early Fifties onwards, and even then it was only gradual. The rising demand for official schools, i.e., secondary and higher education, including from the Catholic element, may have prompted this. ${ }^{4}$

The legacy of the Independent State of Congo (1885-1908)

The state's (i.e., the colonial administration) collaboration with the Catholic missions dates back to the period of the so-called Independent State of Congo, which is sometimes also called the Free Congo State. From the outset, Leopold II had petitioned Belgian missionaries for assistance in the expansion of the colonial project. In response to mounting international criticism of his highhanded behaviour in Congo, the demand for support from Belgian congregations (e.g. to supplement the French support already available) would only grow over time. That the Catholic Church took advantage of its "missionary task" to expand its power in Central Africa is a contested issue. Just as it had in Europe, where, following the schools' war with the liberals, it succeeded in developing a subsidised network of private (denominational) schools, the Catholic Church tried to assert its dominance in the colony during the first half of the twentieth century. And yet, even setting aside the tremendous cultural differences, the situation was significantly different compared to Belgium. Not only did educational inculcation have to start from scratch, the Catholic Church also had to contend with foreign Protestant missions, which had had a strong presence on African soil since time immemorial. Leopold II attempted to lure the church, along with industry, into becoming a reliable partner in the colonial adventure by granting a plethora of material benefits, such as, making land available upon which mission posts could be built.

There were, de facto, official and private (i.e. denominational) schools under Leopold's rule. Naturally the latter were the establishments of the missions - both Protestant and Catholic (e.g., the Jesuit chapel homesteads) - while the former were also exclusively outsourced to Catholic missions as school colonies of the state (Decree of 12 July 1890). Historically-speaking they trace their existence as a sort of relief camp for so-called "wards," often orphans or children who had been separated from their parents during the military raids and the punitive expeditions under Leopold's rule, and who were forced to stay there until the age of 25 . These colonies enforced a strict, almost military discipline, with an emphasis on manual labour in agriculture. The official school colony for boys in Boma was even part of the army. The number of times pupils were whipped in punishment cannot be counted. They were chained, had to carry out forced labour and suffered myriad hardships. If any talk can be had of anything vaguely resembling instruction in these first institutions, then it would concern the acquisition of practical knowledge and skills needed to perform labour in the context of a trade or profession. In 1906, a programme for candidate clerks was established in Boma for example. Without counting seminaries for priests - the first minor seminary dates back to 1899 , and the first major seminary in 1905 - where one could go to discover the pre-eminent truth inherent to faith (the first Congolese priest was ordained in 1917), this was

\footnotetext{
${ }^{4}$ Most of the following data and facts are taken from Depaepe/Van Rompaey, 1995, in which all original sources (archives and printed material) are mentioned. In order to cope with the length of this review article based on our ongoing Congo research, these references are not included here. The same applies to the facts and figures derived from articles and books that we have published afterwards.
} 
probably the highest form of education available in the Independent State of Congo. It goes without saying that these school colonies were heavily criticised, especially by foreign, largely AngloAmerican observers. An international committee of inquiry from 1904 concluded that the international, Protestant schools ran better. A historic lead, which was also reflected in the number of "pupils" - the Protestants were said to have had about 26,700 pupils in 1908 compared to only 19,400 in Catholic institutions.

However, the colonial administration was not deterred by this criticism. Instead it belittled it as propaganda against Leopold's civilising work. The aforementioned vocational school in Boma, and the official vocational schools in Leopoldville and Stanleyville, also founded in 1906, were to serve as a quasi-response. On 26 May of that same year, the Independent State of Congo entered into a convention with the Holy See, which confirmed the preferential treatment of the Catholic missions - more symbolically than in reality - as a political policy. The missions received all kinds of material benefits in exchange for more targeted practical education. And yet the cooperation between civil servants and missionaries was anything but smooth. To the contrary, insofar as specific research has been conducted into this relationship, it conjures up the image of a trail littered with incidents of significant bickering and even harassment, although the principle of the collaboration was never questioned as such.

The horror, the violence, the heinous deeds and abuses that were churned out by the brutalising, colonial "pedagogical" regime from its inception have been described in detail by Jules Marchal, under the pen name A.M. Delathuy (1986; 1992/1994), whose writings were rejected by some critics as biased. Even so, it is primarily on Marchal's work that the American historian Adam Hochschild (1998) based his monumental book on Leopold II's intervention in Congo. Prior to this, more specific educational-historical research had been conducted in the United States, among others by Barbara Yates (1980), who brought the incredibly popular inquiry of the time concerning the "educational-potential of the Negro" out into the open. Although opponents and proponents could be found among the missionaries on this topic (Yates called them pessimists and optimists) most of them settled for a pragmatic compromise. Despite the myriad stereotypes that proliferated in this colonial foray (the significance and courage of those involved merits highlighting), none of these put much stock in the educational potential of Africans. They were - reportedly - entirely devoid of theoretical inclination, being naturally lazy, hot-headed, lewd, polygamous, and so on. From an evangelical perspective, however, they had to try and elevate them to a "higher" level; in that way they could carry out useful labour to the benefit of the colony. All in all, this "civilising process" was akin to a civilising offensive, the aim of which, as it once was on our own shores, was to make individuals tamer and more orderly (i.e., disciplining, rendering more pliant, and literal - domestication).

\section{The Catholic missionary offensive's heyday in the Belgian Congo}

After 1908, when Congo had become a Belgian colony due to pressure exerted by international powers, the collaboration between Church and State continued unabated. And yet, despite its role in creating a specific educational policy, the partnership was never officially recognised. An overly rigid policy framework was considered a nuisance. The Colonial Charter (18 October 1908), which essentially formed the basic legal framework for Belgian administration of the Congo, adopted the principle of freedom of education from the Belgian Constitution (1831) in terms of educational policy. In practice, this meant that the Catholic missions, certainly until the outbreak of the World War II, could go about their business for the most part without any disruption. This led to a gradual 
expansion of the educational offering and an acquisition that also led to, if not a quasi-monopoly, then most assuredly an overwhelming majority of the colony's educational institutions.

I will come back to this shortly; however, I would first like to point out that this "decision" in favour of the Catholic missions was also a solution of convenience, given that for the most part Belgium showed very little interest in the colony. Catholic Jules Renkin, who was also Belgium's first Minister of the Colonies, aptly expressed the public opinion of the time when he let it slip that education in the Congo ought to be as cheap as possible. However, this was juxtaposed with his refusal to disavow the legitimacy behind the lofty mission of Belgians on the ground there to civilize - a discrepancy between rhetoric and reality, far from unusual for the Catholic position, but this also is a side note. In the past (and particularly regarding debate on Leopold II's probable misdeeds), Catholic missionaries revealed themselves to be not only loyal collaborators in the colonial regime, but also as a relatively cheap workforce, largely because they had no wives or children to maintain, and because they were generally satisfied with less, unlike civil servants. The fact that they usually also spoke at least one of the languages and knew the lay of the land made investment in the Catholic missions all the more attractive, in the same way that several nonreligious politicians in Belgium regarded religion, and its concomitant morality, as a potential vehicle for placating the indigenous population.

In the meantime, the Catholics continued to be the most dominant political group in Belgium. During the colonial administration era, they supplied no less than 23 of the 29 ministers, seven (or even eight) of the ten Governor Generals (who had a vital say in actual educational policy as there was little binding legislation in place to enforce it) and about $90 \%$ of the directors of the colonial administration, which meant they definitely need not fear any opposition. The laissez-faire approach of Catholic missionaries was proposed as compensation for the principle of indirect rule, after the example of the British, who targeted the gradual development of the indigenous population. In reality, this theoretical premise was little more than pretext, designed to conceal the absence of real development from the international community.

A true end was put to this laissez-faire for the first time following World War I, by secular liberal Minister of the Colonies, Louis Franck, who mapped out a plan for the social-economic development of Congo that also included education. To the extent that the latter was concerned, he allowed his policy to be shaped to a considerable degree by the committee, established in 1922, that was named after him. It was comprised of senior officials, educators and representatives of various mission congregations, which again gave Catholics a preponderant sway in colonial affairs. Seven of the eleven Franck Committee members were clearly dyed-in-the-wool Catholics. Moreover, the influence of one of the then Catholic Directors on the Ministry of Colonies, Leuven Professor Edouard De Jonghe (see also Schampaert, 2010), was so substantial that the "convention(s)" designed and published by the committee would later be named after him.

Based on various drafts, the committee arrived at a number of recommendations, which would first lead to a new "draft" agreement with the missions halfway through the 1920s; however, the definitive realisation of which would only be achieved (with a programme) in 1929. This delay was not only to be attributed to the political instability during this period (a shocking ten different governments spanned the years between 1918 and 1931) but also by the manifest unwillingness of the Catholic missions to agree to the organisation of a national inspection of their education. Eventually the inspection of all private subsidised education became the responsibility of the Mission Inspectorate, which had to report to the Official Inspectorate (tasked with reporting on the official schools). At the end of the day, however, this government inspection was of little import. In any event, it was obvious that the missions had succeeded in incorporating a buffer into the system, which prevented the government from directly intervening in their schools. It didn't stop 
there, though. Following the introduction of the notion of "national" missions - a statute needed to be eligible for subsidies - the Catholics obtained, as it were, a certain monopoly on subsidised education in Congo. The Protestants only had a single national mission, the Société belge des missions protestantes, which was only active in Rwanda.

The principles set out in the De Jonghe Convention (in principle held to be valid for twenty years), and the programme of 1929 that arose as a result (which the missionaries and the colonials referred to as the yellow brochure), ultimately turned out to be those of the Franck Committee: (1) policy ought to focus on primary education, which needed to align with the lives of the Congolese, rather than stemming from a European perspective; (2) in this regard, moral education must take priority over the acquirement the knowledge (a principle that the Belgian Catholics had already also advocated in their motherland from the middle of the nineteenth century onwards, in their conflict with the liberals); (3) to the greatest extent possible, education had to be organised in an indigenous language; (4) and in which regard, the cooperation with the missions must play the leading role. According to De Jonghe, who had undertaken a research expedition to Congo from July 1924 until January 1925 in preparation of a variety of issues, only the missionaries were capable of sufficient flexibility to adequately achieve the "adaptation" required of the Congolese situation.

The requirement to adapt seemed - in theory at any rate - to be closer to the Anglo-American model of colonisation than that of the French, in which the notion of "assimilation" (the assimilation of the indigenous population to the nation's metropolitan culture) was said to be central. In that sense, it also more or less responded to the recommendations formulated by the Phelps Stokes Fund for seven African colonies in 1922, which included Congo (see also Seghers, 2004). However, it must be clear that these major theoretical frameworks - insofar as they actually signified something in practice - were often primarily used to legitimise the implemented policy a posteriori, thus rendering them subject to heavy "appropriation." Mutatis mutandis, the same applies to the missiological theories put forward concerning evangelisation, in which the same principle of "adaptation" was quite prominent (for example, during the mission weeks, organised in Leuven from 1923 onwards by Jesuit Pierre Charles). Such principles often concealed the utilitarian nature of the "primary" education doled out to the masses, in which the colonial administration's goal was to use, among others, manual labour and religious morality to render the indigenous population submissive, largely through the use of discipline.

In any event, the 1929 programme attempted to operate superficially, rather than to work at a deeper level. In practice, this meant more of a wait-and-see attitude with regard to any organisation of secondary education, and especially higher education, for the Congolese. Instead, the dominant focus was on widespread primary education in the cities and villages. By way of initial primary education, the 1929 plan provided two years of "primary" education in rural areas, with school days lasting no more than four to five hours. The emphasis was put on practical skills and cultivation of a solid work ethic. Alongside religion, the curriculum included reading, writing, and mathematics, as well as singing, callisthenics, manual labour and agriculture, with courses in home economics for young girls. In terms of methodology, the programme recommended "instinctive" and "casual" education, which could elaborate on all kinds of relevant themes through "informal chat" in the local language. In the urban centres and larger missions, a second ranking (of two years) was organised for more motivated pupils. In this bracket, contact with the European culture was sought after because it was considered preparation for specialised studies for office clerks, teachers and craftsmen (they were unable to find sufficient white labour to fill these positions). The next tier were the so-called special schools, in which pupils could complete their professional/vocational education - this also applied to the education of girls, whose personal 
development, indeed, was considered instrumental to the "solving" of societal problems, but to which the yellow brochure rarely paid specific attention.

This was the case, however, in the draft reform of 1938, which emphasised the bifurcation of the "masses" and the "elite" in (primary) education to an even greater degree than the brochure of 1929, and provided for a simplification of the minimum programme while at the same time entailing a weighting of the selection ranking. However, this draft, which also provided for a wide range of advanced courses, was never approved, due to the obstinacy of the missions and the state of war. It would not be until 1948 that a new programme would make its appearance, under the supervision of Catholic Minister Pierre Wigny, and established independently of his ten-year plan for the colony, in 1949 (though it cannot, however, be regarded as entirely separate from it). Increasingly, the programme focused on training an elite and the fine-tuning of selection mechanisms (whereupon it became the missionaries themselves who could set the quota for candidates). And in addition to primary education, the programme provided for a wider range of course components, which continued to entail a level that was highly variable, and was for that matter, quite intentional.

In the interim, however, even before World War II broke out, the untenable position of dominance held by the Catholic Church over (subsidised) education in the colony was becoming increasingly more visible. In the 1930s, on one side, an ever-increasing clamour of voices was heard in favour of subsidising education at the Protestant missions, while on the other, in part due to the economic crisis, there was also growing demand for government intervention.

That the De Jonghe convention had not left subsidised missionary education any worse for wear, is evidenced in its quantitative development. According to the existing - but not always reliable - figures, private subsidised education in Congo and Rwanda-Burundi on 1 January 1930 included 2,722 schools for 128,981 pupils. This figure increased to 5,156 institutions for 246,381 pupils in 1940 and by 1945 it had ballooned to 5,985 institutions for 314,450 pupils. This was almost as high as the number for "free" schools, to which Protestant schools (accounting for 485,058 pupils) in addition to Catholic non-subsidised schools belonged.

\section{Indigenism as educational variant?}

Besides freedom of education, the Belgians also exported the principle of linguistic freedom to the colony. That said, the main objective in using local languages was to facilitate the achievement of their goal of ensuring moralisation took precedence over the acquisition of knowledge in primary education. Education in a European language ran counter to the pedagogical principles of the regulations that had been developed in the interbellum. If the local dialects did not deviate too much from the four common "linguae francae" or the conventional tongue, teachers would instruct their pupils in Ciluba, Lingala, Kikongo or Kiswahili, especially in rural areas. French was optional in rural schools. It was only compulsory in the central (later also called metropolitan) schools. In principle, this arrangement was also maintained in the 1948 programme, although French had gained somewhat more prominence in this version. However, wherever it proved "useful," the missions continued to argue in favour of the local language.

The so-called "indigenists" (their spokespersons initially being Father Boelaert in the 1930s, later followed by Father Hulstaert) specifically championed the use of the local language, i.e., Mongo, in the region around Coquilhatville (Mbandaka) in the Province of Équateur. These indigenists - a small but not irrelevant pedagogical minority - stood in opposition to any assimilationist notions that entailed integration with Western civilisation, even under a system of 
indirect governance. They advocated for group-centred development within the "indigenous" environment, while ensuring that this environment itself was rendered admissible by the civilisation. In so doing they demonstrated respect for the indigenous culture (the destruction of which could not simply be allowed); however, this cannot yet be construed as regard on par with that of European civilisation. Quite the contrary, there was a broad consensus that the Congolese cultures ought to be subordinated to the civilising campaign. The only reason for using this culture and the local Mongo language, according to the indigenists, was for the attainment of this civilising goal. It would make it more appealing to the indigenous population because of the interest expressed in their culture.

All in all, however, the linguistic work of the missionaries must be interpreted within the framework of colonization; i.e. as an attempt to know, to control and to dominate (Fabian, 1983, p. 173). Indeed, the aim of colonial rule was to establish and maintain power, and in this process the missionaries were essential. As the anthropologist Johannes Fabian concludes: "Watching over the purity of Christian doctrine and over the correctness of grammar and orthography were intrinsically related as two aspects of one and the same project" (Id., p. 183).

At first glance, the indigenist reflex also bears resemblance to a number of innovative principles (from the progressive education or "new school" movement) which were also very fashionable in Europe at the time: centred on the child as departure point, to include his or her interests, his or her environment, and so on. We have demonstrated elsewhere that this attitude vom Schwarzen aus (in line with progressive education and the principle of vom Kinde aus) had no roots whatsoever in any emancipatory interest (Depaepe, Simon, and Vinck, 2015). In fact it worked to achieve the opposite, with cultural segregation in one's own environment creating more of an infantilising and patronising effect. Indigenists, like or perhaps even more than ordinary missionaries, were inherently paternalistic. They felt that the Congolese had a duty to preserve their traditional culture. Their disdain for the so-called "évolués" who tried to move up in society using education and who tried to adapt to Western culture (and language), also stemmed from this rationale - as Bambi Ceuppens (2004), among others, amply demonstrated in the quest for parallels with fascistic traits of Flemish nationalism. The motto of Guido Gezelle (a well-known WestFlemish poet) "Wees Vlaming die God Vlaming schiep" (Be a Fleming, that God hath created a Fleming), according to Hulstaert, could reasonably also be applied to the various African tribes (see also Vinck, Simon, and Depaepe, 2016).

For that matter, the fact that French was slowly becoming more popular in the colony need not only be attributed to the ambitions of the évolués, who were attempting to climb the social ladder using education (see, e.g., Meeuwis, 2011). It was only natural that as the colonial structures became increasingly complex, the demand for a single administrative language would grow. Ultimately, this did not prevent the Belgian linguistic conflict from making its way to the colony. Dutch was compulsory in the official education for Europeans (which was introduced in 1946 by the Flemish liberal Godding) from year 3 onwards, and over time Dutch-language divisions were also established, largely under pressure by the metropolitan Flemish organisations. As a result, the indigenous population was also exposed to Dutch, a language they apparently considered the secret language of a large number of missionaries for many years, which is also why they wanted to learn it.

A more general fundamental attitude toward tutelage, or paternalism 
In Belgium, a paternalistic manner was presented as a legitimate and highly desirable development. The title of future Governor General Pierre Ryckmans's 1931 book, Dominer pour servir, left very little to the imagination in this respect. He reiterated ad nauseam that the Congolese did not take any initiative and therefore had to be ordered around; that they were incapable of abstraction and therefore of intellectual training; that it was possible to educate them, but that they required a specific model and example; that they did possess mercantile instinct, but that they preferred to be lazy rather than tired; that they were captive to magical world views and did not seem very susceptible to rational perspectives; that they let their wives do all the hard work and exhibited a substantial sexual appetite, which among others was evidenced in their "polygamy." In view of the inherent "psychology" of the "blacks," in-depth interaction with the West's conceptual heritage was therefore deemed unnecessary. Only elementary education was required for them to function in "their" environment, which in accordance with the metropolitan nineteenth-century pattern, meant that "education" must take precedence over "instruction."

This type of Eurocentric perspective on matters revealed the fundamental paradox (see Depaepe and Hulstaert, 2013), in all its naivety and triviality, which most colonial educators observed being implemented in the field. On one hand, an introduction to the system of Western thought and patterns was indispensable to the success of the colonial enterprise, while on the other, an "excess" of education could result in alienation and uprooted-ness. Both would be hazardous outcomes, not in the least because destabilisation of traditional life among the indigenous population could open the door to potential revolutionary uprising. The question "how far can we/must we/are we allowed to go" was always a background concern, all the more so because the mass expansion of primary education obviously contributed to the demand for "more" education. In any event, they hoped to prevent the Congolese from departing en masse to Belgium as a result. The prevailing regulations on freedom of movement, however, made that scenario rather preposterous.

Incidentally, the interaction with the educational space, in the geographical sense of the word, is a nice example of this patronising, colonial pedagogical approach. Even though it was only after World War II that urban development could really be referred to, the protagonists of missionary evangelisation had, from the beginning of the 20th century, made attempts to ensure that missions be kept outside of the cities as much as possible. According to them, governmental sites, mission posts, and industrial centres were best established separately, so that excessive interference could be avoided. At locations where primary schools were added to the missions, a connection with the model of medieval abbeys (in this respect it was the neo-Gothic style that served as inspiration for the architecture) was often sought after. Given that the educational project was embedded in a catechising and moralisation project, a discourse arose in Congo, more among the Catholic element than that of the Protestant, on the "dangers" of the city and urban culture - a discourse which was, incidentally, easily recognisable in nineteenth century Belgium as well (in the same way that there was a shared preference for the same architecture).

Up until the middle of the previous century, it was in this educational space that the missions tried to socialise the indigenous youth with a mix of elementary education and instruction, to turn them into the submissive aids of the colonial system. That no real effort was made to develop an intelligentsia did not present a problem. The colonial adage at the time was "pas d'élite, pas d'ennuis" (no elite, no troubles). And yet the rapid social transformations following World War II, such as an increase in paid labour and the concentration of the population in the Congolese cities, would put an end to this overly simplistic, colonial dream. 
The pivotal 1950s

That World War II caused a mental fault line in colonial thinking is not implausible. Regardless of the stubborn paternalism of the ecclesiastical and civilian authorities, it became apparent that the indigenous population had "grown up" overnight, and were clamouring for their rights. In any event, they refused to be mindlessly ordered around any longer. The first strikes and various rebellions in the army were a good example of this. They forced the Belgians to make quick decisions, which in the long run served as the harbingers of change in the colonial and missionary mind-set. On one side, the call for university education grew increasingly louder, while on the other the Catholic educational monopoly came increasingly under fire, not in the least from Belgian liberals and socialists who wished to play a more active role in colonial policy by establishing a secular state education system.

After World War II, the Ministry of Colonies was managed by the Flemish liberal and secular Robert Godding in the governments of national unity. He had already granted subsidies to the Protestant missions in 1946, largely under the influence of the British and American forces that had liberated Belgium. At the same time, official state education for white children was established (with the foundation of three state secondary schools).

Catholic dominance in the field of colonial education was further eroded in the 1950s. Several left-wing critics denounced the excessive thirst for power of the missions. Delay tactics and the party appointments of the Christian-Democrat Ministers Pierre Wigny (1947 - 1950) and Andries Dequae (1954) most assuredly did nothing to still the storm of protest. When a socialist-liberal government came to power in 1954, with the liberal Auguste Buisseret as Minister of the Colonies, this immediately led to the establishment of neutral, official (state) schools for the black population. As many as three hundred of these schools would be founded over a four-year period, including the first interracial secondary school in 1955. The report by the pedagogical "mission" to Congo mandated by Buisseret (15 October - 11 December 1954) legitimised this ruling. In their report, Coulon, Deheyn and Renson (and with them the officials of the departments of Education and Colonies which clearly backed this endeavour) classified the level of the Catholic missionary education as entirely inadequate (incurring immediate protest by the missions, among others, and Jesuit Van Wing in particular). At the same time, however, the subsidies for these mission schools were also scaled back, which effectively ran contrary to the budgetary agreements of the convention of 1952 (which ultimately replaced the convention of 1929). These measures, and the new, predominantly left-wing appointments in the colonial administration, chafed at the missions and culminated in a battle among Congolese schools, which was conducted in the margin of the (second) Belgian School War, but which was expressed largely in writing and oral debate, rather than actual combat in the field. On 15 January 1955, the Catholic missions threatened to close their schools if the budgetary restrictions were not reversed. Fearful that the Congolese education system would collapse, Buisseret caved on the 26th of January, overturning the deliberate measures. But this did not yet herald an end to this small-scale school war. Again in 1955, a new row erupted concerning school building subsidies. To shatter this stalemate, the Canon Joseph Moerman, President of the Bureau de l'Enseignment Catholique would later engage in negotiations with the Minister on behalf of the missions. In August 1956, they arrived at a compromise, the so-called Buisseret-Thompson-Moerman Agreement, which fixed the respective 45\%-45\%-10\% distribution formula for the official (or state) Catholic and Protestant education systems in Congo.

In the meantime, the government's educational meddling meant that educationalization continued to grow exponentially. From 1954 until 1957, the number of pupils increased by more than $50 \%$, from $1,112,562$ to $1,692,218$ - a growth curve hitherto unheard of. If we use the number 
of pupils as a criterion, the proportion of official state education in 1958 at the primary school level was just $3 \%$, while at the secondary education level, $14 \%$ of pupils were enrolled in official schools. This percentage further increased in technical and higher education to $42 \%$ and $45 \%$ respectively. However, this just concerned small figures. In 1957, over $95 \%$ of all pupils were either in nursery school (4\%) or in primary education $(91.3 \%)$. The same applied to the presence of "natives" in the so-called interracial, metropolitan education system. In 1953, they accounted for $0.15 \%$ of the total number of pupils $(21 / 13,669)$ whereas by 1957 this proportion had risen to $4.05 \%(909 / 22,430)$. This trend is thrown into even sharper relief when only indigenous attendance at metropolitan secondary schools is taken into consideration. These were only attended by $4.3 \%$ non-Europeans, including Asians $(0.9 \%)$ and "mulattoes" (1.5\% "registered" mulattoes and $0.4 \%$ who were not). The amount of Congolese in the official secondary schools in 1957 never exceeded $1.5 \%$ $(59 / 4,138)$, which leads us to conclude that these "metropolitan" schools were de facto European schools, not intended for Africans in the first place.

Nonetheless, the development of an official state education system meant that the Catholic schools were forced by the exigencies of competition to further "metropolise" their programmes, which had already been purported in the 1948 curriculum reform. At the time this also opened new venues for Catholics to develop general secondary and higher education, in addition to the minor and major seminaries which had already been training indigenous priests from the inception of colonialisation. In 1947, the Lovanium university centre was founded in Kisantu (where programmes for medical and agricultural "assistants" had been established as early as 1925 and 1932 respectively) in association with the Catholic University of Leuven (KU Leuven) and the local Jesuits (Mantels, 2007; Roobrouck, 2005). In 1950, it was transferred to Kimuenza, near the then capital of Leopoldville. In 1953 the prep year began, while the first academic year only started in October 1954 - just six years before the Congolese Declaration of Independence. Lovanium had 33 students at the time, including 11 Congolese. In 1956 the official university of the Belgian Congo and Rwanda-Burundi was founded in Elisabethville (present-day Lubumbashi) as a counterpart to the Catholic University. However, it goes without saying that these efforts were unable to stem the tide of weighty repercussions brought in by the unilateral politics of the past fifty years. On the eve of independence, the Belgians had only trained a handful of indigenous university graduates. Only $0.1 \%$ of the Congolese school population was enrolled in higher education in 1960, a figure that contrasted sharply with the figure of $0.4 \%$ for all of Africa and 3\% for the entire world at the time. Apparently, the sudden acceleration in the Congolese independence process had entirely overwhelmed the Belgians and their "educational gradualism" policy.

For several authors, the Belgian School Wars, and the clear recognition for the first time of the export of its concomitant divisions, were factors that accelerated the independence process (see Boyle, 1995), as well as growing the resistance (mainly, but not exclusively from the évolués) against the colonial practices of the Belgians (see Yervasi, 2008; Kadima-Tshimanga \& Ilunga, 1989). Next came the Brussels World's Fair in 1958. It was supposed to be a meeting place for the évolués from all over Congo, who not only got a taste of the fine accoutrements of Western prosperity, but more importantly were also treated humanely by whites (often for the first time). Until then, painstaking effort had been made to keep them in the colony (Stanard, 2012, p. 16), with study in Belgium also withheld from their legitimate options. It was highly exceptional that Congolese were allowed to study in Belgium during and after the interwar period (see, e.g., Zana, 2015). In 1947, only 10 Congolese were officially registered in Belgium and from 1958 to 1959, there were only 19 Congolese students enrolled in the then bilingual Catholic University of Leuven, of which 18 were men. 
... and relations with the évolués

The concept of évolués in Congolese society was significantly intertwined with the notion of gradual development. To Buisseret, who could incidentally count on the sympathy of various segments of the indigenous population because of his educational policy, the "evolués" had to develop into a kind of middle class, a true black bourgeoisie, as it were. This would not only constitute the backbone of the future colony, but would also safeguard against uprisings and revolutionary ideas, both from within and without.

Four elements were involved in the "évolué" concept's definition (see Mutamba, 1998): the education received, their income, their role and responsibility in society, and finally their level of moral development. Two judicial interventions attempted to regulate the status of the évolué: (1) the acquisition of the so-called "cartes de mérite civique" (1948) and (2) the "immatriculation" system (1958). In the first intervention, however, the level of education received did not play a decisive role. Individuals had to prove that they had performed colonial services, had to demonstrate civilised behaviour, have a Western household and be able to resist the lure of superstition and polygamy. According to reports, in 1952 only 452 of these cards had been issued, which had multiplied nearly four-fold in 1958, with 1,557 issued cards, but which nevertheless still covered only a terribly meagre group. No wonder then, that the first judicial intervention was branded a failure in the end. The second intervention would suffer the same fate. The aim of this "immatriculation" was to grant special status to those who could be "assimilated" - the only indigenous elite deemed capable of achieving some form of western civilisation. The intention was to separate this elite (which included a large number of indigenous priests) from the large group of évolués in order to grant them the same civil rights as the Europeans in Congo (in the context of travel, among others), which, however, did not mean full legal equality at all. Apparently, the demand arose for a more restrictive status for the "true" évolués, who hoped to distance themselves from the "alleged" ones (distinguished by snobbishness, extravagance and materialism, and bending the rules in respect to the polygamy prohibition, which they cleverly managed to circumvent). Because the stakes were high, monitoring was a good deal stricter here than for the certificates of civic merit. Committees specially established for this purpose inspected the level of civilisation for not only the immatriculation candidate, but also spouses and any children. At the end of 1958, only 217 persons had successfully acquired immatriculation out of a total number of évolués that, depending on the source, was estimated at between approx. 15,000 and 40,000 (and comprised not more than 5\%, at the most, of the African craftsmen in the Congo).

Such measures could hardly conceal the existence of a real colour bar. ${ }^{5}$ All in all, the newly acquired culture remained a local one for the noirs perfectionnés that concerned individuals, a culture which could not be considered part of the global white culture (see, e.g., Tödt, 2012; Ringrose, 2008). It was a sort of intermediary culture, one which, on the one hand, allowed for some upward mobility by the top tier of the colonial population within the system, but which on the other, also perpetuated the disparity with the colonial rulers. Ultimately even the "evolved" Congolese remained a kind of second-class citizen within the colony. During the turbulent era of the 1950 s, the whites sought to maintain order and authority by keeping control of the colony themselves. The "evolved black elite," whose grievances naturally formed the foundation of the radical wing of anti-colonial nationalism, were not merited equal treatment, despite their "evolved"

\footnotetext{
${ }^{5}$ The fact that Thomas Kanza, one of the very few Congolese trained in Belgium before independence, did not receive the same salary in Congo as the Belgian colonists, is, so to say, a "textbook example" of this. See Roobrouck, 2005, p. 192
} 
behaviour. As an évolué explained to François Ryckmans - the grandson of the former Governor General: "le plus élevé des Noirs était encore en dessous du plus petit des Blancs" (even the highest-ranking black was still deemed less worthy than the lowest-ranking white) (Ruckmans, 2010a, p. 5). They would never eat or live together, that much was obvious. Different codes of conduct applied to the colonial rulers and their African employees (or servants). The fact that the largely ignored group of "mulattoes" (cf. Ghesquière and Kanobana, 2010) - the biological evidence of the colonial "encounter" - almost exclusively consisted of children of a white father and an African mother already says enough about the dominant macho behaviour of the colonials. Much stricter standards applied to their spouses, who outsourced household work to local "boys." The fact that the évolue Jean Lema mustered up the courage in 1952 to invite a Belgian woman to dance with him is often cited in any historiography about the Congo as an example of the mental barrier that continued to exist between blacks and whites in Congo (see, e.g., Ryckmans, 2010b).

In educational spaces in the 1950s, however, a general obliviousness to the rage beneath the surface seemed to prevail. Efforts to adapt to the challenges of the new social situation did not result in any profound change in mentality. While the Church was able to demonstrate more concern for the grievances of the Congolese, the fostering of critical consciousness by missionary education continued to be avoided based on fear of the social ramifications. However paradoxical it may sound, not wanting to relinquish this paternalistic strategy accelerated the demise of Belgian paternalism. The perpetuation of patronising behaviour only increased the locals' variance with colonisation. According to the "pedagogical" dream of Belgian educators in Congo, the native population had to be slowly but surely prepared for their independence. The only way to do this was to keep them at a "near distance," or to enforce "distant proximity." On the one hand, African identity was reinforced through education and instruction to avoid further uprooting: educators even made attempts to adopt new-fangled ideas and develop a proper African pedagogy. However, these initiatives were actually designed to emphasise this distant proximity. By starting with their own "environment," the aim was to not accentuate the disparity with the European "level of development." On the other hand, the western civilisation model continued to define the development and modernisation of Congo, resulting in the perpetuation of hierarchical added value (and appeal) - despite all the well-intentioned new education - positions that seemed not to be for Africans, in that the key posts all remained in Belgian hands.

What that all specifically entailed in the day-to-day classroom practices can, perhaps, be inferred through the analysis of films, among other sources. For example, Gerard De Boe (see Martens, 2010), a former teacher and health official in the colony, initially commissioned to create propaganda films for the colonial administration, and who later set up his own production company, released a documentary in 1950 entitled: Zwarte elite voor de toekomst (A black elite for the future). ${ }^{6}$ It is obvious that this elite will not hold any high-ranking positions. What it boils down to instead is agricultural work in palm gardens, carpentry or ceramics. Moreover, the discipline entailed in gymnastics (a Foucaultian position of power subjecting the body to control) is strongly reminiscent of the time-honoured colonial preference for order and authority. The propaganda film avoids showing physical punishment (which did occur daily according to several witnesses). In contrast, a missionary is given the floor to discuss some sort of self-government (also an appropriation of the new school movement), but it is that the control - the (in)visible hand that manages everything - is exercised not by the boys, but by the white priest. Apparently the most progressive circles of missionary education had concluded that governing the soul (after the title

\footnotetext{
${ }^{6}$ The booklet edited by Martens, 2010, contains a double DVD with historic films about the Congo. "A black elite for the future" is one of them.
} 
of Nikolas Rose's famous book: Rose, 1991) often proved much more effective than the biopolitics of controlling the body.

Finally, we will briefly discuss the Tokende ${ }^{7}$ - Lingala for "Let's go" - print (see Catteeuw et al., 2005). De Boe was commissioned to make this film in 1957 by the Catholic missions in anticipation of the aforementioned Expo 58 (he also used fragments of earlier work for this compilation). The documentary needed to provide an overview of the heroic significance of the Catholic missions in Congo. It starts with a mission liturgy in a Belgian church, after which the various achievements of the missionaries are shown. Naturally, these also relate to education, which remains, however, subordinate to the religious objectives. The film ends with the final vows ceremony of African monks and nuns, bringing the film full circle. The missionary work proved fruitful. Evangelisation and spiritual care, which invariably included education, passed into indigenous hands. Due to the near exclusive focus on the missionary propaganda - "we do it at least as well as in the motherland" - we get a very detailed picture of all kinds of processes of school behaviour. The following examples spring to mind: the role-play/conversation lesson between an indigenous teacher and pupil who, albeit in the correct conjugation of the personal pronoun, repeats exactly what the teacher says to him in the third person about a matchbox (and thus also shows what the school makes of what is announced as a conversation lesson on the blackboard); or think of the song rehearsed earlier with a white priest that seamlessly transitions into the performance of the professionally trained boys' choir Les troubadours du Roi Baudouin; the glorified practice lesson on birds, using imitation models, wall charts and diagrams on the blackboard at the primary education teacher training college for girls; the "interracial" dialogue between a white and a coloured person who recite Latin and Greek texts; the just as exaggerated physics lectures at the university, where a white priest explains Faraday's Law to both an interested Belgian and a young Congolese student, etc. In this filmed dramatization, the day-to-day school rituals and realities are revealed, as it were, in a grotesque manner, for the intention is to exaggerate them, to inflate them. This is educational behaviour at its best, looking its best: the best infrastructure, the best schools, the best teachers, the best pupils. As a result, we can also learn quite a lot about the daily educational practice in Congo. The film, after all, actually shows how the ideal of pedagogical practice was imagined. That picture, in fact, hardly differs from what was customary in Belgium. But it certainly did help in producing the idea of a "primitive Other," capable of evolution in the direction of the Belgians, who simultaneously defined themselves as "advanced" (see Stanard, 2012).

\section{Conclusion}

Generally speaking, we can conclude that the same "grammars" of educationalization, which had been developed in Belgium in the nineteenth and twentieth centuries, were transposed as much as possible to Congo. This is apparent from the imitation of classical education and the introduction of school rituals within the limited possibilities of the colonial context. In view of the principles of the "colonial pedagogy," it is clear that the pedagogical relationship in the classroom was not at all designed to achieve "emancipation," "autonomy," "freedom of expression," or any of the other fine notions intended to achieve the educational objectives of the so-called emancipatory pedagogy of the late 1960s. The main emphasis was on inevitable submission through discipline and order. But here too, there must be space for some subtlety and nuance, for behind the hard, unpalatable stance

\footnotetext{
${ }^{7}$ A copy of this movie is kept at the KADOC - the study and documentation centre of the KU Leuven for the Catholica. We are grateful to them as they provided us with a personal exemplar for our study.
} 
of the educators there often lurked a deep fondness for Africans. However, it is clear that from the perspective of colonial and missionary education, the asymmetric relationship between the educator and the pupil (which, moreover, had more than a symbolic significance in the context of legitimising the European presence in Africa), could not (or hardly) be denied. An obvious world of difference spanned the incredible naivety, which was also apparent in schoolbooks and school songs - for that reason called petits témoins de la grande illusion coloniale (Depaepe et al., 2003; Kita and Depaepe, 2004) - and the often erudite knowledge of some of the stakeholders in Congo, just as there were geographical and, related to this, pedagogical differences in emphasis and methods between the various educational orders. This led to rivalry and conflicts between the various orders in the field more than a few times. Catholic missionary activities in Congo, as a result, should not be regarded as a unified effort.

At the same time, even the most progressive missionaries, colonists and colonials still made certain miscalculations in terms of the educational policy they enforced. The biggest problem which naturally is also part of the colonial pedagogical paradox - was the évolués. As the most striking creation of the colonial education regime, they should have, in fact, been the figurehead of Belgian educational investments in Congo. However, this group was considered an intermediary group in every sense of the word. Because of their education, évolués seemed better off than the ordinary Congolese; however, they were still kept at a clear distance by the average white man in the colony. At no time were they involved in any way in the process of the design of Congo's future. At most, the Belgians considered them the executors of the plans they had devised. From a colonial perspective, education still implied "caring for," meaning making decisions for those who were still not yet permitted to act on their own behalf or undertake anything. Therefore, the recent plea for the "recolonization" of Africa (Gilley, 2017) seems to me highly unrealistic. ${ }^{8}$ Thinking that colonialism can be resurrected without the usual oppression, occupation, and exploitation, is not only intrinsically paternalistic, but also utopic, as it continues to dichotomize between "white" and "black," between "European" and "African" cultures - which are, in fact, all constructions of colonial codification (Ranger, 2005, p. 250). It is simply that kind of dichotomization (between e.g. the "noir primitif" vs. "noir instruit") that caused the ongoing colonization of indigenous masses during the Mobutu-regime (MacGaffey, 1998; Kadima-Tshimanga \& Ilunga, 1989; see also Altbach, 1971) and is indirectly, at least to a certain extent, co-responsible for "Congo's violent peace" of the last decades (Berwouts, 2017; Nzongola-Ntalaja, 2007). As long as one is not capable of "endogenizing" universal values and human rights by stimulating the self-concept and selfimage of the African people from the inside, the supposed hierarchy and one-way traffic between a "superior" centre and an "underdeveloped" periphery will continue. Without such a future creating a horizon of hope, true African emancipation, possibly through personalist dialogue and authentic encounter(s) between North and South, will remain excluded (De Visch, 1996).

So it will come as no surprise that many of the Congolese we surveyed have very mixed feelings about the colonial period. On the one hand, there was some positive appreciation for what the Congolese could learn in general from the Belgians and more specifically through the missions. On the other hand, the Congolese felt that the entire educational campaign was one great missed opportunity. If you want to take this last conclusion to a higher theoretical level by linking back to the original hypothesis, then the conclusion must inevitably be "the more educationalizing education was, the less educational it has been." So it is with keen interest that I look forward to any research that will test this forthright statement in other (colonial or imperial) contexts.

\footnotetext{
${ }^{8}$ The Editors would like to note that this piece has been withdrawn by Third World Quarterly.
} 


\section{References}

Altbach, P.G. (1971). Education and Neocolonialism: A Note. Comparative Education Review, 15(2), 237-239.

Berwouts, K. (2017). Congo's geweldadige vrede. Berchem: EPO. (originally in English: Conflict and Struggle Since The Great African War. London: Z-books).

Boyle, P.M. (1995). School Wars: Church, State, and the Death of the Congo. The Journal of Modern African Studies, 33(3), 451-468.

Catteeuw, K., Dams, K., Depaepe, M., \& Simon, F. (2005). Filming the Black Box: Primary Schools on Film in Belgium: a First Assessment on Unused Sources. In U. Mietzner, K. Myers, \& N.

Peim (Eds.), Visual History. Images of Education, (pp. 203-231). Oxford/Bern/Berlin/Bruxelles/Frankfurt am Main/New York: Peter Lang.

Celis, G.R. (1990). La faillite de l'enseignment blanc en Afrique noire. Paris: L'Harmattan.

Ceuppens, B. (2004). Congo made in Flanders?: koloniale Vlaamse visies op "blank" en "zwart" in Belgisch Congo. Ghent: Academia Press.

De Herdt, T. \& Titeca, K. (2016). Governance with empty pockets: The education sector in the Democratic Republic of Congo. Development and Change, 47(3), 472-494.

Delathuy, A.M. (1986). Jezeuieten in Kongo met zwaard en kruis. Berchem: EPO.

Delathuy, A.M. (1992/1994). Missie en staat in Oud-Kongo 1880-1914. 2 vols. Berchem: EPO.

Depaepe, M. (1997). Demythologizing the educational past: An endless task in History of Education. Historical Studies in Education/Revue d'histoire de l'éducation, 9(2), 208-223.

Depaepe M. (1998). 'Rien ne va plus ...' The Collapse of the Colonial Educational Structures in Zaïre (1960-1995). Education and Society. International journal in education and sociology, 16(1), 37-53.

Depaepe, M. (2002). The practical and professional relevance of educational research and pedagogical knowledge from the perspective of history: Reflections on the Belgian case in its international background. European Educational Research Journal, 1(2), 360-379.

Depaepe, M. (2012). Between Educationalization and Appropriation. Selected Writings on the History of Modern Educational Systems. Leuven: Leuven University Press.

Depaepe, M. (2013). Sous le signe du paternalisme: les politiques éducatives des Belges au Congo (1908-1960). In B. Falaize, C. Heimberg \& O. Loubes (Eds.), L'école et la nation. Actes du séminaire scientifique international. Lyon, Barcelone, Paris, 2010, (pp. 435-442). Lyon: ENS éditions.

Depaepe, M. (2014). Writing Histories of Congolese Colonial Education: An Historiographical View form Leuven, Belgium. In B. Bagchi, E. Fuchs, \& K. Rousmaniere (Eds.), Connecting Histories of Education. Transnational and Cross-Cultural Exchanges in (Post-) Colonial Education, (pp. 41-60). New York/Oxford: Berghahn.

Depaepe, M. (2017). Onderwijs in Congo. Van paradepaardje van de missionering tot oorzaak van het postkoloniale debacle? In B. Pattyn \& P. d'Hoine (Eds.), Wetenschap en utopie. Lessen voor de eenentwintigste eeuw 2017, (pp. 205-231). Leuven: Leuven University Press.

Depaepe, M. \& Van Rompaey, L. (1995). In het teken van de bevoogding. De educatieve actie in Belgisch-Kongo (1908-1960). Leuven/Apeldoorn: Garant.

Depaepe, M., Briffaerts, J., Kita Kyankenge Masandi, P, \& Vinck, H. (2003). Manuels et chansons scolaires au Congo Belge. Leuven: Leuven University Press.

Depaepe, M., Herman, F., Surmont, M., Van Gorp, A., \& Simon, F. (2008). About Pedagogization: From the Perspective of the History of Education. In P. Smeyers, \& M. Depaepe (Eds.), 
Educational Research: The Educationalization of Social Problems, (pp. 13-30). Dordrecht: Springer.

Depaepe, M. \& Simon, F. (1995). Is there any Place for the History of "Education" in the "History of Education"? A Plea for the History of Everyday Educational Reality in- and outside Schools. Paedagogica Historica, 31(1), 9-16.

Depaepe, M. \& Simon, F. (2009). Sources in the Making of Histories of Education: Proofs, arguments, and other reasonings from the historian's workplace. In P. Smeyers \& M. Depaepe (Eds.), Educational Research: Proofs, Arguments, and Other Reasonings, (pp. 2339). Dordrecht: Springer.

Depaepe, M. \& Hulstaert, K. (2013). Creating Cultural Hybridity by Exporting Metropolitan Structures and Cultures of Schooling and Educationalization? The Emergence of a Congolese 'Elite' in the 1950s as a Starting Point for Further Research. European Educational Research Journal, 11(2), 202-214.

Depaepe, M. \& Hulstaert, K. (2015). Demythologising the educational past: an attempt to assess the 'power' of education in the Congo (DRC) with a nod to the history of interwar pedagogy in Catholic Flanders. Paedagogica Historica, 51(1-2), 11-29.

Depaepe, M., Simon, F., \& Vinck, H. (2015). Une « nouvelle » éducation pour les Congolais? Indigénisme, nouvelle éducation et pédagogie normative. In J. Droux \& R. Hofstetter (Eds.), Globalisation des mondes de l'éducation. Circulation, connexions, réfractions XIXe-XXe siècles, (pp. 259-280). Rennes : Presses Universitaires de Rennes.

Devisch, R. (1996). Universiteiten in Zuid-Saharisch Afrika: tussen verwestersing en culturele verworteling. Mededelingen van de Zittingen van de Koninklijke Academie voor Overzeese Wetenschappen, 42(2), 155-182.

Fabian, J. (1983). Missions and the Colonization of African Languages: Developments in the Former Belgian Congo. Canadian Journal of African Studies, 17(2), 165-187.

Foucault, M. (1971). The Archaeology of Knowledge and Discourse on Language. New York: Pantheon.

Fraiture, P.-Ph. (2008). Belgium and its Colonies. Introduction. In P. Poddar, R.S. Patke and L. Jensen (Eds.), A Historical Companion to Postcolonial Literatures: Continental Europe and its Empires, (pp. 7-12). Edinburgh: Edinburgh University Press.

Fredriksen, B. (2005). Le système éducatif de la république démocratique du Congo: Priorités et alternatives. S.1.: Région Afrique, Département du développement humain, Banque Mondiale.

Ghesquière, K. \& Kanobana, S. (2010). De bastaards van onze kolonie. Verzwegen verhalen over Belgische metissen. Roselare: Roularta Books.

Gilley, B. (2017). The Case for Colonialism. Third World Quarterly. doi:10.1080/01436597.2017.1369037.

Hanf, T. (1969). Erziehungsreform im Kongo. Eine Fallstudie zur gesellschaftspolitischen Problematik der Übertragbarkeit moderner Bildungsmodelle auf Entwicklungsländer. Zeitschrift für Politik, 16(4), 465-475.

Hochschild, A. (1998). King Leopold's Ghost. A story of greed, terror and heroism in colonial Africa. Boston (MA): Houghton Mifflin.

Kadima-Tshimanga, B. \& Ilunga Kongolo, L.-M. (1989). L'évolué congolais et la Révolution de 1959 au Congo belge. Analyse de textes. In Révolte et Société, (pp. 173-181). Paris: Publications de la Sorbonne.

Kita Kyankenge Masandi, P. \& Depaepe, M. (2004) La chanson scolaire au Congo Belge. Anthologie. Paris: L'Harmattan. 
Mantels, R. (2007). Geleerd in de tropen. Leuven, Congo \& de wetenschap, 1885-1960. Leuven: Universitaire Pers Leuven.

Martens, E. (Ed.) (2010). Belgisch Congo Belge gefilmd door / filmé par / filmed by Gérard De Boe, André Chauvin \& Ernest Genval. Brussels: CINEMATEK.

MacGaffey, W. (1982). Education, Religion, and Social Structure in Zaire. Anthropology \& Education, 13(3), 238-250.

MacGaffey, W. (1998). Am I Myself? Identities in Zaire, Then and Now. Transactions of the Royal Historical Society. 6th S. (vol. 8), 291-307.

Meeuwis, M. (2011). Bilingual Inequality: Linguistic Rights and Disenfranchisement in late Belgian Colonization. Journal of Pragmatics, 43(5), 1279-1287.

Minten, L., Depaepe, M., De Vroede, M., Lory, J., Simon, F., Mertens, R., \& Vreugde, C., Les statistiques de l'enseignement en Belgique. L'enseignement primaire 1830-1992. 5 Vols. Bruxelles: Archives générales du Royaume.

Mudimbe, V. (2009). Lex perfecta, praecepta recta. Mediteren over bemiddelen In V. Viaene, D. Van Reybrouck, \& B. Ceuppens (Eds.), Congo in België. Koloniale cultuur in de metropool, (pp. 315-333). Leuven: Leuven University Press.

Mutamba Makombo Kitatshima, J.-M. (1998). Du Congo Belge au Congo Indépendant : 19401960. Emergence des " évolues » et genèse du nationalisme. Kinshasa: Institut de Formation et d'Etudes Politiques.

Nzongola-Ntalaja, G. (2007). The Congo from Leopold to Kabila: A People's History. London/New York: Zed Books.

Poncelet, M., André, G., \& De Herdt, T. (2010). La survie de l'école primaire congolaise (RDC) : héritage colonial, hybridité et résilience. Autrepart, 2(n. 54), 23-41.

Ranger, T. (2005). The Invention of Tradition in Colonial Africa. In E. Hobsbawm \& T. Ranger (Eds.). The Invention of Tradition, (pp. 211-262). Cambridge: Cambridge University Press.

Ringrose, P. (2008). Evolués. In P. Poddar, R.S. Patke \& L. Jensen (Eds.), A Historical Companion to Postcolonial Literatures: Continental Europe and its Empires, (pp. 24-26). Edinburgh: Edinburgh University Press.

Roland, E. (2017). Généalogie des dispositifs éducatifs en Belgique du XIVe aux XXe siècle. (Thèse de doctorat). ULB, Faculté des Sciences Psychologiques et de l'Education, Bruxelles.

Roobrouck, J. (2005). Utopie of universiteit ... of beide? Een geschiedenis van de universiteit Lovanium (1948-1971). Leuven: KU Leuven, Faculteit der Letteren (Licentiaatsverhandeling in de geschiedenis).

Rose, N. (1991). Governing the Soul: The Shaping of the Private Self. London/New York: Routledge.

Ryckmans, F. (2010a). Préface. In A. Cornet and F. Gillet, Congo-Belgique, 1955-1965. Entre propagande et réalité. Bruxelles: Renaissance du livre, CEGESOMA.

Ryckmans, F. (2010b). Mémoires noires. Les Congolais racontent le Congo belge. 1940-1960. Bruxelles: Editions Racine.

Ryckmans, P. (1931). Dominer pour servir. Bruxelles: Lib. A. Dewit.

Schampaert, A. (2010). Edouard De Jonghe, 1878-1950. Wegbereider voor koloniale instellingen en administratie. Bijdragen tot eigentijdse geschiedenis, 6(n.22), 93-112.

Seghers, M. (2004). Phelps-Stokes in Congo. Transferring educational policy to govern metropole and colony. Paedagogica Historica, 40(4), 455-477.

Stanard, M.G. (2012). Selling the Congo. A History of European Pro-Empire Propaganda and the Making of Belgian Imperialism. Lincoln (NE): University of Nebraska Press. 
Tenorth, H-E. (1996). Lob des Handwerks. Kritik der Theorie - Zur Lage der pädagogischen Historiographie in Deutschland. Paedagogica Historica, 32(2), 343-361.

Tödt, D. (2012). "Les Noirs Perfectionnés". Cultural Embourgeoisement in Belgian Congo during the 1940s and 1950s. Berlin: Humboldt University (Working Papers des Sonderforschungsbereiches, 640, Nr. 4).

Van Reybrouck (2010). Congo: een geschiedenis. Amsterdam: De Bezige Bij.

Vinck, H. (2007). Le manuel scolaire au Congo belge. L'état de la recherche. History of Education and Children's Literature, 2(2), 69-78.

Vinck, H., Briffaerts, J., Herman, F., \& Depaepe, M. (2006). Expériences scolaires au Congo Belge. Etude explorative. Annales Aequatoria, 27, pp. 5-101.

Vinck, H., Simon, F., \& Depaepe, M. (2016). Gustaaf Hulstaert, autor de manuales escolares en el Congo: pionero paradójico y controversial (1900-1990). In L.E. Galván Lafraga, L. Martínez Moctezuma \& O. López Pérez (Eds.), Más allá del texto. Aurores, redes del saber y formación de lectores, (pp. 433-465). México: Centro de Investigaciones y Estudios Superiores en Antropología Social; Universidad Autónoma del Estado de Morelos; El Colegio de San Luis.

Yates B. (1963). Structural Problems in Education in the Congo (Leopoldville). Comparative Education Review, 7(2), 152-162.

Yates, B. (1971). African Reactions to Education: The Congolese case. Comparative Education Review, 15(2), 158-171.

Yates, B. (1980). White Views of Black Minds: Schooling in King Leopold's Congo. History of Education Quarterly, 20(1), 27-52.

Yervasi, C. (2008). Anti-colonial Resistance in the Former Belgian Colonies. In P. Poddar, R.S. Patke \& L. Jensen (Eds.), A Historical Companion to Postcolonial Literatures : Continental Europe and its Empires, (pp. 14-19). Edinburgh: Edinburgh University Press.

Yoon Jeong, N. (2016). Education en RDC: la situation en 20 points. Retrieved from http://ponabana.com/la-situation-de-leducation-en-rdc-en-20-points/. Posted December 2016. Accessed January, 2017.

Zana Etambala, M. (2015). Panda Farnana, le roi Albert Ier et la question de la méthode educative afro-américaine pour le Congo: 1911-1921. Museum Dynasticum, 27(1), 25-47. 